\title{
Factor Structure of the Perceived Stress Scale (PSS) in a Sample from Mexico
}

\author{
Mónica Teresa González Ramírez and René Landero Hernández \\ Universidad Autónoma de Nuevo León
}

\begin{abstract}
The aim of this study was to analyze the cultural adaptation of the European Spanish version of the Perceived Stress Scale (PSS; Cohen, Kamarak, \& Mermelstein, 1983), for its use in Mexican samples. Using a random sample of students, internal consistency was analyzed and the factor structure of the Spanish version of the PSS was compared with the factor structure found in the English version. Internal consistency was adequate $(\alpha=$ $.83)$ and confirmatory factor analysis corroborated the factor structure. Factor 1 explained $42.8 \%$ of the variance and Factor 2 accounted for 53.2\%. The goodness-of-fit measures also revealed an adequate fit. The cultural adaptation of the PSS was also evaluated with satisfactory results.
\end{abstract}

Keywords: PSS, psychometric properties, Spanish, Mexico, perceived stress

\begin{abstract}
El estudio tiene como propósito valorar la adaptación cultural realizada a la versión española de la Escala de Estrés Percibido (Cohen, Kamarak y Mermelstein, 1983), para ser utilizada en muestras de México. Se analizó la consistencia interna y la estructura factorial de la versión en español del PSS y se comparó con la estructura factorial encontrada para la versión en inglés, utilizando una muestra aleatoria de estudiantes. Los resultados indican una adecuada consistencia interna $(\alpha=.83)$ y se confirma la estructura factorial al utilizarse análisis factorial confirmatorio; con el Factor 1 explicando un $42.8 \%$ de la varianza y el Factor 2, un 53.2\%, así como estadísticos de ajuste aceptables en el AFC. Asimismo, se evaluó, con resultados satisfactorios, la adaptación cultural realizada para el PSS.

Palabras clave: PSS, propiedades psicométricas, español, México, estrés percibido
\end{abstract}

Correspondence concerning this article should be sent to Mónica Teresa González Ramírez. Mutualismo 110, Col. Mitras Centro, 64460 Monterrey, N.L., México. Phone. (81)8333-7859. fax: (81)8348-3781.E-mail: monygzz77@yahoo.com

Translation: Virginia Navascués Howard 
There are many approaches to and formulations of the term stress. It can be understood as a phenomenon of the external environment—painful stimulation, noise, arguments, among others-in which case, stress is considered an independent variable. It can be considered a response by the individual—sympathetic arousal, release of catecolamines or cortisol, anxiety, anger, among others-in which case, stress acts like a dependent variable. And it can be seen as an interaction (transaction) between the individual and the environment-a process-(Sandín, 1999).

With regard to these three approaches, Lazarus (1999) stated that it is inappropriate to define psychological stress either as the stimulus or triggering event (the stressor) or as a response or reaction (organic reaction generated by the stressor). In these cases, it is more appropriate to refer to psychosocial or physiological stress. Sandín (1999) noted that psychosocial stress refers to life events (stressors) and physiological stress to a perturbation of the homeostasis. The present study focuses exclusively on psychological stress.

Lazarus and Folkman (1984) proposed that (psychological) stress should be considered a particular relation between the individual and the environment, which is appraised by the individual as threatening or overwhelming his resources, and which jeopardizes his wellbeing. This definition of stress by these authors is known as the transactional perspective of stress, according to which, both internal and external conditions must exist for a stress response to occur and it is precisely the relation between them that generates the occurrence of stress and its individual characteristics. This explains why individuals can respond differently to the same stimulus and, depending on their history, experiences and personal characteristics, they will tend to manifest different interpretations and coping styles in each situation (Taboada, 1998).

Therefore, in the transactional viewpoint of Lazarus and Folkman, the concept of cognitive appraisal is the central idea. Appraisal is defined as the cognitive mediator of the stress reaction; it is a universal process by which people constantly evaluate the meaning of what is happening, in relation to their personal wellbeing.

Lazarus (1999) stated that a person presents stress only if an event prevents or threatens the achievement of important goals and intentions or it jeopardizes highly valued expectations. The degree of stress is related to the intensity of this threat and partially to the beliefs and expectations that individuals think may be achieved or thwarted. The transactional definition of stress contemplates environmental and personal characteristics and their relative importance; the transactional (or relational) meaning provides another necessary part of the process of stress, based on the subjective appraisal of the personal importance of events.

Research on stress has frequently been an essential part of many areas of psychology. For example, for some time in health psychology, researchers have reported evidence that psychological, behavioral, and environmental factors affect the functioning of the immunological system in human beings (Sarason \& Sarason, 1987). Stress and its relation with health has been one of the topics that has awakened the most interest in research in the past decades (Sandín, 1999). Along this line, Segerstrom and Miller (2004) carried out a meta-analysis of more than 300 empirical articles describing the relation between stress and the parameters of the immunological system, concluding that stress actually alters immunity.

The relevance of psychological stress in research leads to the need for valid and reliable instruments to measure it. Considering the transactional definition of stress, there is an instrument, designed by Cohen, Kamarak, and Mermelstein (1983), which is theoretically congruent for its measurement. These authors thought that Lazarus' proposals about stress had not been accompanied by valid measurements of perceived stress and, so, they created the Perceived Stress Scale (PSS) in order to measure the degree to which life events are appraised as stressful. Thus, this method of assessing stress reflects the definition of psychological stress proposed by Lazarus and Folkman (1984).

Recently, Remor (2006) reported that the use of the PSS in various contexts has increased. He also commented that there are some studies about the psychometric properties of the PSS and he presented some data from Spanish samples in this work.

The following study about the validity and reliability of the scale is noteworthy: of the original version of the PSS (in English), only one study was detected, carried out by Cohen and Williamson (1988), which includes a factor analysis as part of the statistical analysis procedures. The study was carried out with a sample of 960 men and 1,427 women from the United States, average age 42.8 years ( $S D$ $=17.2$ ). The authors performed exploratory factor analysis, with principal component analysis and varimax rotation, finding two factors that conjointly accounted for $41.6 \%$ of the variance $(25.9 \%$ the first factor and $15.7 \%$ the second one). Cronbach's alpha for the total scale reached the value of .75 .

With regard to the versions of the PSS in Spanish, no publications were detected of studies of the internal structure of the scale. In the search, both the translation carried out in Spain by Remor and Carrobles (2001) and other adaptations carried out in Mexico ${ }^{1}$ were considered.

\footnotetext{
1 All the versions of the PSS are available at the Website of the Laboratory for the Study of Stress, Immunity and Disease of the Carnegie Mellon University, at http://www.psy.cmu.edu/ scohen/index.html.
} 
Taking the above into consideration, González (2006) conducted exploratory and confirmatory factor analysis of Remor and Carrobles' (2006) Spanish version of the PSS with a sample of 283 women from Mexico. The factor structure reported by Cohen and Williamson (1988) was confirmed, with the exploratory factor analysis yielding two factors that conjointly accounted for $48.5 \%$ of the variance. In the confirmatory factor analysis, an estimated variance of 50\% was found for Factor 1, and of 70\% for Factor 2, as well as adequate goodness-of-fit statistics. The distribution of the PSS items in both factors matched the initial outline of positive or negative items. Taking this into account, Cohen and Williamson indicated that, for purposes of measuring the perception of stress, the distinction between two factors is irrelevant and only one stress score should be considered.

Regarding the internal consistency of the PSS, Remor and Carrobles (2001) obtained a value of $\alpha=.67$, and Remor (2006) a value of $\alpha=.81$. However, when used in the Mexican population (Landero \& González, 2004), item 12 did not perform well (a low and negative correlation with the rest of the scale, $r=-.05)$. The poor performance of item 12 was confirmed in another sample with students (González \& Landero, 2005); this item obtained a correlation of -.02 with the rest of the scale. In view of its poor performance, item 12 was eliminated from the analyses (including the factor analyses) to improve the measurement of stress in the study of González (2006).

Taking the above into consideration, item 12 was adapted, as we considered that perhaps its wording ("How often have you found yourself thinking about things that you have to accomplish?") had not been completely understood by the Mexican subjects (taking into account that this was the Spanish version of the PSS). Likewise, the comprehension of the entire scale was appraised, comparing it with the original version in English.

Thus, the goal of the present study was to evaluate the cultural adaptation carried out on the Spanish version of the Scale of Perceived Stress for its use in samples from Mexico.

\section{Method}

\section{Participants}

The participants were 365 psychology students, from just one university, from a population of 2,410 , randomly selected, taking into account the distribution by sex and study schedule. The sample is distributed as follows: $20.5 \%$ were male and $79.5 \%$ were female. Mean age of the participants was 20.48 years $(S D=3.62)$, median of 20 years; only 13 participants were 26 years old or older. Regarding civil status, $95.9 \%$ of the participants were single, there was only one single mother, and 14 were married.

\section{Instruments}

Stress Perceived Scale (PSS; Cohen, Kamarak, \& Mermelstein, 1983). There are three versions of the PSS: one with 4 , one with 10 , and one with 14 items. The translation into Spanish performed by Remor and Carrobles (2001) corresponds to the 14-item version, which is the version that was adapted culturally to Mexico, as it had been used in previous studies and, at that time, we knew of no other translations carried out for Mexico.

Thus, the version we used has 14 items and is rated on a 5-point Likert type scale, ranging from 0 (never) to 4 (very frequently). Scores of items 4, 5, 6, 7, 9, 10, and 13 are reversed. Higher scores correspond to higher perceived stress. Internal consistency and factor structure data are mentioned in the introduction.

Beck Depression Inventory (BDI; Beck, Ward, Mendelson, Mock, \& Erbaugh, 1961). In order to check convergent validity, a comparison was made with the BDI, which assesses mainly cognitive symptoms of depression, an aspect theoretically related to psychological stress (Lazarus, 1999; Sandín, 1999). This inventory is made up of 21 items with four response options that identify the severity/intensity of the symptom. Beck, Steer, and Garbin (1988) indicated that, in various studies, the internal consistency of the scale reached adequate values (Cronbach's alpha between .76 and .95 ). In the present work, the value of alpha was .80 .

Scale of Emotional Exhaustion (in Spanish, "Escala de Cansancio Emocional", ECE; Ramos, Manga, \& Moran, 2005). A comparison was also made with this 10 -item scale. In the study of Ramos et al., the ECE yielded one sole factor that accounted for $40 \%$ of the variance. Consistency as measured by Cronbach's alpha coefficient was .83 , and in the present study, .89. According to Maslach (2003, cited in Ramos et al.), emotional exhaustion is the first stage of burnout. In university students, burnout manifests as emotional exhaustion (Ramos et al.).

\section{Procedure}

Taking into account that in previous studies, item 12 had shown poor performance in Mexican samples, two groups of approximately 30 psychology students in each group were asked about the meaning of the item ("How often have you found yourself thinking about things that you have to accomplish?”; in Spanish "¿Con que frecuencia has pensado en las cosas que te quedan por lograr?"). They responded that they related it to their goals ("How often do you think about your goals?") and not with the original idea of the item in the English version ("In the last month, how often have you found yourself thinking about things that you have to accomplish?"). Thus, item 12 was modified ("How often have you thought about the things you have not yet finished [pending solution]?”, in Spanish "¿Con que frecuencia has 
pensado sobre las cosas que no has terminado [pendientes de hacer]?"). The comprehension of the entire scale was also evaluated, comparing it with the English version, concluding that the remaining items were adequate.

The participants were informed of the aim of the investigation and their written consent was obtained before administering the instruments. Administration of the PSS, the BDI, and the ECE was carried out with other instruments, as the present work is a phase of a more extensive investigation.

\section{Statistical Analyses}

For the purpose of this investigation, the factor structure of this adapted version of the PSS was examined and compared with the factor structure found in the study of Cohen and Williamson (1988) and with that of González (2006). In addition, the reliability (internal consistency) of the scale was evaluated with Cronbach's alpha, and its convergent validity by comparing it with the BDI with Spearman's correlation, because of the lack of normality in the distribution of the variables. Likewise, the levels of stress as a function of sex were compared, using the Mann Whitney $U$ test.

The exploratory factor analyses were performed with the SPSS, version 12.0, and principal components and oblimin rotation were used to extract the factors. Principal components is the most frequently used and the most appropriate method if the goal is to reduce the data (Fabrigar, MacCallum, Wegener, \& Strahan, 1999). Oblique (Oblimin) rotation allows correlation among factors (Fabrigar et al.).

To detect the number of factors, the recommendations of Fabrigar et al. (1999) of using several criteria, were followed. In this case, three methods were used:

- Rule K1: the most well-known method to select the number of factors is the Kaiser criterion of calculating the Eigenvalues of the correlation matrix to determine how many of these Eigenvalues are larger than 1, which indicates the number of factors recommended (Fabrigar et al., 1999).

- Scree test: by means of the scree plot, the last substantial leap in the magnitude of the Eigenvalues is identified and as of this Eigenvalue, the number of factors is determined (op cit.).

- MAP method (Minimum Average Partial method): Velicer (1976) proposed this procedure, which uses as criterion the partial correlations among the original variables, after having eliminated from them the data reproduced by the factors already extracted. Velicer indicated that the MAP procedure is better than the $\mathrm{K} 1$ rule and the scree plot, and it tends to underestimate the number of factors when they are poorly defined (loadings less than .5) and the proportion of variables per factor is high. In order to implement it, the MATRIX procedure proposed by Ruiz and San Martín (1993) was used.
For the confirmatory factor analysis, we used AMOS 5.0 , with the maximum likelihood method, which is commonly used in structural equation models (Ruiz, 2000; Schermelleh-Engel, Moosbrugger, \& Müller, 2003). This method assumes normality, and, although this assumption is difficult to meet in psychology, maximum likelihood estimations are robust (Schermelleh-Engel et al.).

The following goodness-of-fit statistics were analyzed:

- Chi square: the purpose of this statistic is to contrast the null hypothesis that all the residuals are null (Ruiz, 2000). The limit of this test is that its value depends on sample size. Therefore, with large samples, the statistic tends to increase.

- Normed Chi-Square (NSC): this index is used to compare the magnitude of $\chi^{2}$ with the degrees of freedom $\left(\chi^{2} / d f\right)$; for a good fit, this proportion should be as small as possible, and values lower than 3 indicate a good or acceptable fit (Schermelleh-Engel et al., 2003).

- Absolute Fit Indexes: These indexes evaluate whether the proposed model reproduces the data adequately. The following indexes were calculated: the goodness of fit index (GFI) the adjusted goodness of fit index (AGFI) - in which the values near to 1 indicate adequate fit; the root mean square residual (RMR) and the root mean square error of approximation (RMSEA) - in which small values indicate better fit; thus, values between .05 and .08 could indicate a reasonable error of approximation.

- Incremental fit indexes: these indexes measure the improvement of fit by comparing the proposed model with a model that assumes that there is no association among the observed variables and which is usually called the independence model. The following are incremental fit indexes: the normed fit index (NFI), the Tucker-Lewis index (TLI), the comparative fit index (CFI), and the incremental fit index (IFI )the values of these indexes should be close to 1 to indicate a good fit.

\section{Results}

The mean of the PSS was 21.9 ( $S D=7.03$, range 3-46), and the median was 21 . As mentioned above, according to the Kolmogorov-Smirnov test, the data were not normally distributed (KS $=.061, p=.002)$. Regarding internal consistency, the alpha coefficient was .83 , the correlation of the items with the total scale was adequate, with the lowest correlation occurring in item $12(r=.25)$. Likewise, the analysis showed that by eliminating items, the value of Cronbach's alpha did not improve.

When performing the exploratory factor analysis, the KMO value (.87) was acceptable. The sphericity test was significant; therefore factor analysis of these items was suitable. 
Regarding the number of factors, the scree plot (Figure 1), the criterion of Eigenvalue higher than 1, and the MAP method all suggested two factors. These two factors accounted for $48.02 \%$ of the variance $(32.61 \%$ by Factor 1). The correlation between the two factors was -.27 .

\section{Scree Plot}

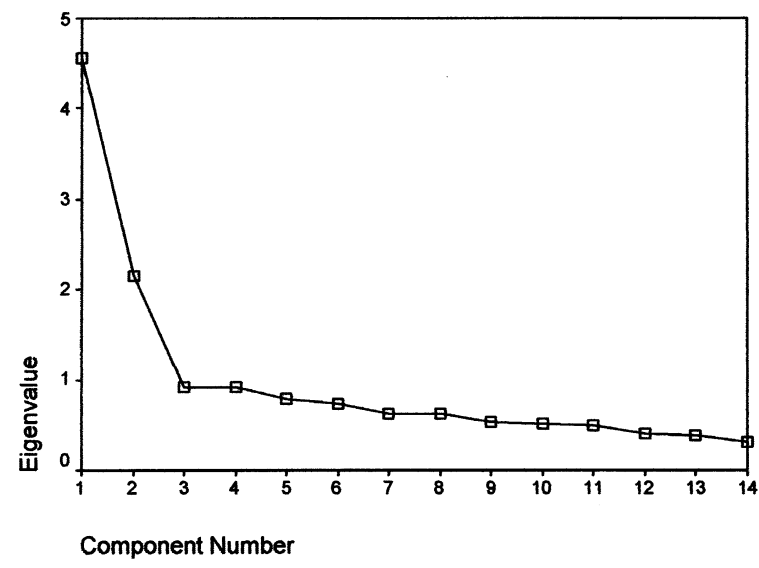

Figure 1. Scree plot of the PSS.
In Table 1 is presented the factor structure of the PSS, which confirms the one reported for the English version of the PSS (Cohen \& Williamson, 1988), and the one detected in the study of González (2006), where item 12 did not have an adequate correlation with the rest of the items. The items are grouped in the factors according to their original wording, as positive or negative items. The value of Cronbach's alpha for Factor 1 was .83 and that of Factor 2 was .78. No item presented a negative correlation with the rest, so the adaptation of the scale was considered adequate.

Confirmatory factor analysis was used to confirm the facture structure presented in Table 1 . The model with standardized results is presented in Figure 2. All the parameters were significant. The indicators of the fit of the model (see Table 2) indicated that the model is adequate; only NFI presented a value that suggests that the model could be improved; the NSC indicated a good fit $\left(\chi^{2} / d f=\right.$ 2.64). The correlation between the factors was -.46 ; the estimated variance for Factor 1 was $42.8 \%$ and that of Factor 2 was $53.2 \%$. Therefore, it was concluded that this model is adequate.

Table 1

Factor Structure of the PSS

\begin{tabular}{|c|c|c|}
\hline How often...... & Factor $1(\alpha=.83)$ & Factor $2(\alpha=.78)$ \\
\hline E1. have you been upset by something that happened unexpectedly? & .100 & .749 \\
\hline E2. have you felt that you were unable to control the important things in your life? & -.282 & 630 \\
\hline E3. have you felt nervous and "stressed"? & -.075 & .684 \\
\hline E4. have you dealt successfully with day to day problems and annoyances? & .792 & .073 \\
\hline $\begin{array}{l}\text { E5. have you felt that you were effectively coping with important changes that were } \\
\text { occurring in your life? }\end{array}$ & .789 & .031 \\
\hline E6. have you felt confident about your ability to handle your personal problems? & .828 & .019 \\
\hline E7. have you felt that things were going your way? & 610 & -.222 \\
\hline E8. have you found that you could not cope with all the things that you had to do? & -.147 & .452 \\
\hline E9. have you dealt successfully with irritating life hassles? & .731 & -.021 \\
\hline E10. have you felt that you were on top of things? & .543 & -.162 \\
\hline $\begin{array}{l}\text { E11. have you been angered because of things that happened that were outside of } \\
\text { your control? }\end{array}$ & .060 & .724 \\
\hline E12. have you found yourself thinking about things that you have to accomplish? & .193 & .629 \\
\hline E13. have you been able to control the way you spend your time? & .518 & .074 \\
\hline E14. have you felt difficulties were piling up so high that you could not overcome them? & -.188 & .583 \\
\hline
\end{tabular}

Table 2

Goodness-of-fit Indexes for the PSS

\begin{tabular}{|c|c|c|c|c|c|c|c|c|c|c|}
\hline \multirow{2}{*}{ Model } & \multirow{2}{*}{$\chi^{2}$} & \multirow{2}{*}{$d f$} & \multicolumn{4}{|c|}{ Absolute fit indexes } & \multicolumn{4}{|c|}{ Incremental fit indexes } \\
\hline & & & GFI & AGFI & RMR & RMSEA & NFI & TLI & CFI & IFI \\
\hline Model with 2 correlated factors & 200.979 & 76 & .925 & .897 & .053 & .067 & .873 & .900 & .916 & .917 \\
\hline
\end{tabular}




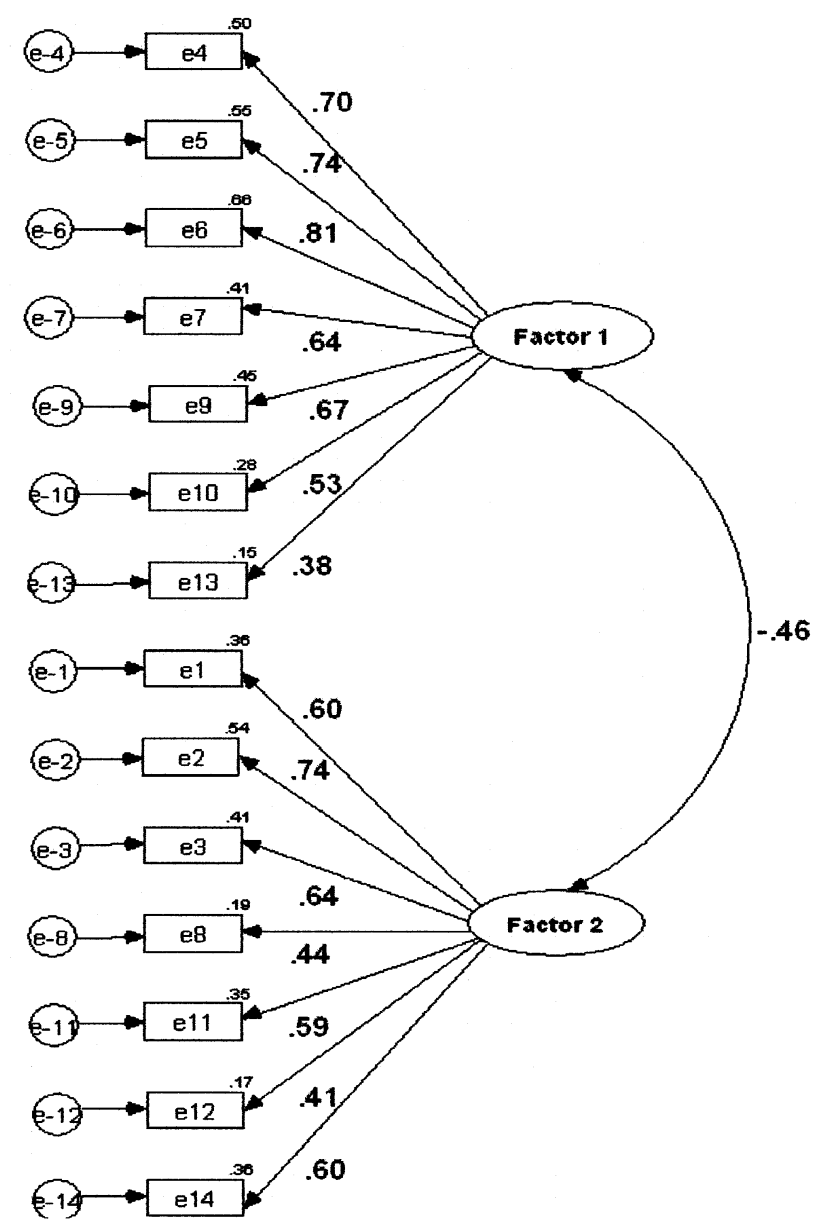

Figure 2. Confirmatory factor analysis of the PSS.

To examine convergent validity, the correlation between the PSS, the BDI, and the ECE was calculated. As expected, both the latter scales correlated positively with the PSS $\left(r_{\mathrm{s}}\right.$ $=.553, p=.001$ and $r_{\mathrm{s}}=.521, p=.001$, for BDI and ECE, respectively).

Lastly, we calculated the PSS scores as a function of sex, finding that the women's mean was higher than the men's $(M=22.3, S D=7.2$ and $M=20.6, \mathrm{SD}=6.18$, for women and men, respectively). However, this difference did not reach statistical significance $(p=.079)$.

\section{Discussion}

The Stress Perceived Scale (PSS) has been shown to have good internal consistency in Spanish samples (Remor \& Carrobles, 2001; Remor, 2006), and the internal consistency found in this adaptation for Mexico is also adequate.

The factor structure revealed confirms the structure detected in the English version of the PSS (Cohen \& Williamson, 1988) and in the study by González (2006). The items are grouped into the factors according to their original wording as positive or negative items. It is noteworthy that Cohen and Williamson considered that the distinction between two factors is irrelevant and only one stress score should be considered in the measurement of the perception of stress.

Likewise, regarding the grouping of the items according to their wording, Carretero-Dios and Pérez (2005) pointed out that exploratory factor analysis only groups similar correlations but such grouping can be due to aspects than other conceptual ones and that, when one half of the items are written positively and the other half negatively, they frequently split up into two clear factors. One factor gathers all the positive items and the other all the negative ones. Thus, the format of the items may carry more weight than their conceptual meaning.

Regarding convergent validity, as expected, the correlations with the measures of depression and emotional exhaustion were adequate. Despite the fact that the PSS was not compared with the same constructs as in the study of Remor (2006), the correlational analyses carried out provide more evidence of the convergent validity of the scale.

When comparing the scores of men and women, the results are congruent with those of Remor and Carrobles (2001), who reported a higher mean in women. However, as in the present study, the difference was not significant.

As a limitation, we point out that the sample was made up exclusively of students from one university career. However, the mean PSS score $(M=21.9, S D=7.03)$ is similar to the one reported in clinical samples in the studies of Remor and Carrobles of $2001(M=22.57, S D=8.67)$ and of Remor of $2006(M=25.0, S D=8.1)$. The same holds for the range (3-46) with the range reported in the study of Remor (3-45). These data suggest that university students present perceived levels of stress similar to those of other populations, although their stressors may be different.

On the basis of the previous studies and the data presented, we consider that the PSS is an instrument with adequate psychometric properties (internal structure, reliability as internal consistency, and convergent validity) and is congruent with the transactional definition of stress. Therefore, its use can be recommended for investigations that are based on the proposals of Lazarus and Folkman about psychological stress. The version analyzed in this study is included in the annex.

Lastly, we recommend the present study be considered a complement to the work by Remor (2006). Likewise, we recommend that the decision about which PSS version to use in different Spanish-speaking countries be treated with caution, given the cultural differences that, as shown, can affect the performance of the PSS.

\section{References}

Beck, A., Ward, C., Mendelson, M., Mock, J., \& Erbaugh, J. (1961). Inventory for measuring depression. Archives of General Psychiatry, 4, 561-571. 
Beck, A., Steer, R., \& Garbin, M. (1988). Psychometric properties of the Beck Depression Inventory. Twenty-five years of evaluation. Clinical Psychology Review, 8, 77-100.

Carretero-Dios, H., \& Pérez, C. (2005). Normas para el desarrollo y revisión de estudios instrumentales. International Journal of Clinical and Health Psychology, 5, 521-551

Cohen, S., Kamarak, T., \& Mermelstein, R. (1983).A global measure of perceived stress. Journal of Health and Social Behaviour, 24, 385-396.

Cohen, S., \& Williamson, G. (1988). Perceived stress in a probability sample of the U.S. In S. Spacapam \& S. Oskamp (Eds.), The social psychology of health: Claremont Symposium on Applied Social Psychology (pp. 31-67). Newbury Park, CA: Sage.

Fabrigar, L., MacCallum, R., Wegener, D.T., \& Strahan, E.J. (1999). Evaluating the use of exploratory factor analysis in psychological research. Psychological Methods, 4, 272-299.

González, M. (2006). Confirmación de un modelo predictivo para la salud, a través de ecuaciones estructurales. Research obtain the Diploma of Advanced Studies (DEA). Madrid: Universidad Nacional de Educación a Distancia (UNED).

González, M., \& Landero, R. (2005). Síntomas psicosomáticos y estrés en estudiantes de psicología. Manuscript submitted for publication.

Landero, R., \& González, M. (2004). Variables psicosociales como predictoras de la salud en mujeres. Revista de Psicología Social, $19,255-264$.

Lazarus, R.S., \& Folkman, S. (1984). Stress, coping and adaptation. New York: Springer.

Lazarus, R. (1999). Stress and emotion. A new synthesis. New York: Springer (Spanish translation: Estrés y emoción. Manejo e implicaciones en nuestra salud. Bilbao: Desclée de Brouwer, 2000.)

Ramos, F. Manga, D., \& Moran, C. (2005). Escala de Cansancio Emocional (ECE) para estudiantes universitarios: Propiedades psicométricas y asociación. INTERPSIQUIS. Retrieved April 22, 2005. Available at: http://www.psiquiatria.com/articulos/ estres/20478/
Remor, E. (2006). Psychometric properties of a European Spanish version of the Perceived Stress Scale (PSS). The Spanish Journal of Psychology, 9, 86-93.

Remor, E., \& Carrobles, J. (2001). Versión Española de la escala de estrés percibido (PSS-14): Estudio psicométrico en una muestra VIH+. Ansiedad y Estrés, 7, 195-201.

Ruiz, M.. (2000). Introducción a los modelos de ecuaciones estructurales. Madrid: Ediciones UNED.

Ruiz, M., \& San Martin, R. (1993). Una implementación del procedimiento MAP para la determinación del número de factores. Psicothema, 5, 177-182.

Sarason, I.G., \& Sarason, B.R. (1987). Abnormal psychology: The problem of maladaptive behavior ( $5^{\text {th }}$ ed.). Englewood Cliffs, NJ: Prentice-Hall. (Spanish translation: Psicología anormal: el problema de la conducta inadaptada ( $7^{\text {th }}$ ed.). México: Prentice-Hall Hispanoamericana, 1996).

Sandín, B. (1999). Estrés psicosocial. Madrid: Klinik.

Schermelleh-Engel, K., Moosbrugger, H., \& Müller, H. (2003). Evaluating the fit of structural equation models: Tests of significance and descriptive goodness-of-fit measures. Methods of psychological research online, 8, 23-74.

Segerstrom, S., \& Miller, G. (2004). Psychological stress and the human immune system: A meta-analytic study of 30 years of inquiry. Psychological bulletin, 130, 601-630.

Taboada, M.L. (1998). Eventos traumáticos y reacciones de estrés: identificación y manejo en una situación de desastre natural. Psiquiatría.com. Revista Electrónica, 2 (4). Retrieved March 31, 2000. Available at: http://www.psiquiatria.com/psiquiatria/ vol2num4/art_7.htm

Velicer, W.F. (1976). Determining the number of components from the matrix of partial correlations. Psychometrika, 41, 321-327.

Received August 19, 2006

Revision received December 21, 2006

Accepted January 24, 2007 


\section{Annex}

\section{Adaptation of the PSS (14 items) for Mexico [in Spanish]}

\begin{tabular}{|c|c|c|c|c|c|}
\hline $\begin{array}{l}\text { Marca la opción que mejor se adecúe a tu situación actual, teniendo en cuenta el último mes. } \\
\text { Durante el último mes: }\end{array}$ & $\stackrel{\widetilde{U}}{\Xi}$ & 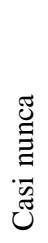 & 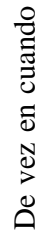 & $\begin{array}{l}\stackrel{̊}{\Xi} \\
\stackrel{\Xi}{\Xi} \\
\Xi \\
\ll\end{array}$ & 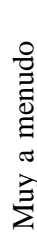 \\
\hline E1. ¿Con qué frecuencia has estado afectado/a por algo que ha ocurrido inesperadamente? & 0 & 1 & 2 & 3 & 4 \\
\hline E2. ¿Con qué frecuencia te has sentido incapaz de controlar las cosas importantes de tu vida? & 0 & 1 & 2 & 3 & 4 \\
\hline E3. ¿Con qué frecuencia te has sentido nervioso/a o estresado/a (lleno de tensión)? & 0 & 1 & 2 & 3 & 4 \\
\hline E4. ¿Con qué frecuencia has manejado con éxito los pequeños problemas irritantes de la vida? & 0 & 1 & 2 & 3 & 4 \\
\hline $\begin{array}{l}\text { E5. ¿Con qué frecuencia has sentido que has afrontado efectivamente los cambios importantes } \\
\text { que han estado ocurriendo en tu vida? }\end{array}$ & 0 & 1 & 2 & 3 & 4 \\
\hline E6. ¿Con qué frecuencia has estado seguro/a sobre tu capacidad de manejar tus problemas personales? & 0 & 1 & 2 & 3 & 4 \\
\hline E7. ¿Con qué frecuencia has sentido que las cosas te van bien? & 0 & 1 & 2 & 3 & 4 \\
\hline E8. ¿Con qué frecuencia has sentido que no podías afrontar todas las cosas que tenías que hacer? & 0 & 1 & 2 & 3 & 4 \\
\hline E9. ¿Con qué frecuencia has podido controlar las dificultades de tu vida? & 0 & 1 & 2 & 3 & 4 \\
\hline E10. ¿Con qué frecuencia has sentido que tienes el control de todo? & 0 & 1 & 2 & 3 & 4 \\
\hline $\begin{array}{l}\text { E11. ¿Con qué frecuencia has estado enfadado/a porque las cosas que te han ocurrido estaban fuera } \\
\text { de tu control? }\end{array}$ & 0 & 1 & 2 & 3 & 4 \\
\hline E12. ¿Con qué frecuencia has pensado sobre las cosas que no has terminado (pendientes de hacer)? & 0 & 1 & 2 & 3 & 4 \\
\hline E13. ¿Con qué frecuencia has podido controlar la forma de pasar el tiempo (organizar)? & 0 & 1 & 2 & 3 & 4 \\
\hline E14. ¿Con qué frecuencia has sentido que las dificultades se acumulan tanto que no puedes superarlas? & 0 & 1 & 2 & 3 & 4 \\
\hline
\end{tabular}




\section{ORDER FORM}

\section{THE SPANISH JOURNAL OF PSYCHOLOGY}

Please enter my annual subscription (2006) at the following rate (singles issues half price):
$\square$ Individual Rate
$\square$ Institutional Rate

$\begin{array}{llll}\square \text { Spain } & 20 \text { euros } & \square \text { Spain } & 25 \text { euros } \\ \square \text { Europe } & 23 \text { euros } & \square \text { Europe } & 30 \text { euros } \\ \square \text { Other Countries } & 25 \text { euros } & \square \text { Other Countries } & 30 \text { euros }\end{array}$

\section{Method of Payment}

Bank money order payable to:

Tesorería UCM - Recaudatoria - Vicerrectorado Extensión Universitaria

Caja de Madrid

Avda. Complutense, s/n, 28040 Madrid (Spain)

To account No.: 2038 / 1526 / 93 / 6000042505

\section{Credit Card}

$\begin{array}{ll}\square \text { Visa } & \square \text { American Express } \\ \square \text { Mastercard } & \square \text { Diner's Club }\end{array}$

Card No.:

Expiry Date:

Signature:

Date:

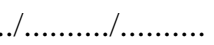

\section{Ship to:}

Name:

Address:

Postal code/Zip: City/State:

Country:

Send this order form to: Servicio de Publicaciones

Universidad Complutense

Isaac Peral s/n

E-28040 Madrid (Spain) 